\title{
Interactive comment on "Analytical Study of North Indian Oceanic Cyclonic Disturbances with Special Reference to Extremely Severe Cyclonic Storm Fani: Meteorological Variability, India's Preparedness with Terrible Aftermath" by Soumen Chatterjee
}

\section{Soumen Chatterjee}

geosoumchat@gmail.com

Received and published: 30 October 2020

Respected Sir, I want to thank for your constructive comments on my manuscript. As I have focused on the analytical study of North Indian Oceanic cyclonic disturbances, I have included the long-term (of last 150 years) annual and seasonal distribution of tropical cyclones over the Arabian Sea (AS) and Bay of Bengal (BoB). It would help us to understand the most affected regions by cyclones over the North Indian Ocean

Printer-friendly version

Discussion paper 
(NIO). On the other hand, to give a more specific example on the terrible aftermath over the eastern coast, I have selected one of the recent and rarest cyclonic storms Fani with its detailed meteorological variability with overall India's preparedness. It would also help to understand how the local and national government have tackled this deadly cyclone and what could be done to minimize the casualty to face that kind of monstrous cyclone in near future. That is the main reason behind the selection of the only one extreme event (Fani) with detailed scenario in the present manuscript. Firstly, you have stated that "The main factor of the correlation was discussed with the effect of the cyclones, but flooding disasters are not only related to the rainfall, but also surface elevation, water system distribution, urban development, etc. However, in this article, only the affected area (distance) of the cyclones is considered, and other factors should be considered". I am completely same-minded to you. For that reason, I have tried to include one paragraph at the end of the "5.2 Inundation detail" section after line number 216 to correlate the inundation with surface elevation, water system distribution, urban development, etc. That paragraph with a new figure has been given below: The maximum flood extent of the study area can be found up to 30 meters altitude from the mean sea level (MSL). The calculated areal extension of flooding (up to $75 \mathrm{~km}$ inside from the coast) based on surface elevation also helps to establish the same fact (Figure 9). Nearly $69.96 \%$ of the total inundated area is extended up to 10 meters altitude from MSL. On the other hand, $21.26 \%$ of the flood has occurred between 10-20 meters and only $7.96 \%$ of the total flooded area has been found in between 20-30 meters altitudinal extension. As the ESCS Fani has made the landfall near Puri of Odisha, the interfluve region of Bhargabi and Kaathajodi River has experienced severe flooding. The heavy rainfall has caused flooding in the deltaic portion of Mahanadi River for having lower altitude $(<10$ meters from MSL) and the presence of distributaries and innumerable rivulets. Besides, the interfluve regions of Haldi-Rupnarayan, Silabati-Dwarakeswar and Ganges deltaic portion of West Bengal has also experienced flooding. No urban area except Puri has been affected due to flooding during this cyclonic event, but the large infrastructural destruction has been

Printer-friendly version

Discussion paper 
made by cyclonic storm Fani due to high velocity of gusty wind in almost every small to large urban centres of the coastal districts.

NHESSD

Secondly, you have also stated that "Base on the result, only possible to evacuation plan were proposed as the government actions. In this case, the cost might be very high with the dense crowd and conservative hazard mapping". I also completely agree with you. As that portion of the country are very densely populated and several billions of people inhabit in this place, taking a particular preparedness plan is very challenging for the high and very densely populated place. For that reason, I have stated one short-term and one long-term plan that would help to tackle that kind of disastrous natural hazards: [1] Evacuation from the track of the cyclone (short-term plan): We need to build sufficient numbers of cyclone and flood shelters so that evacuated people get protection during the storm event and the death toll can be reduced. [2] Housing schemes (long-term plan): The several state-level housing schemes and national housing schemes like Indira Awas Yojana (IAY) and Pradhan Mantri Awas Yojana (PMAY) for the economically weaker section can also cause the advancement towards a longterm solution to ensure full resilience against cyclonic storms with time. Hopefully, I have been able to meet your queries.

Interactive comment on Nat. Hazards Earth Syst. Sci. Discuss., https://doi.org/10.5194/nhess2020-287, 2020.

Printer-friendly version

Discussion paper

Interactive

comment

Discussion paper 


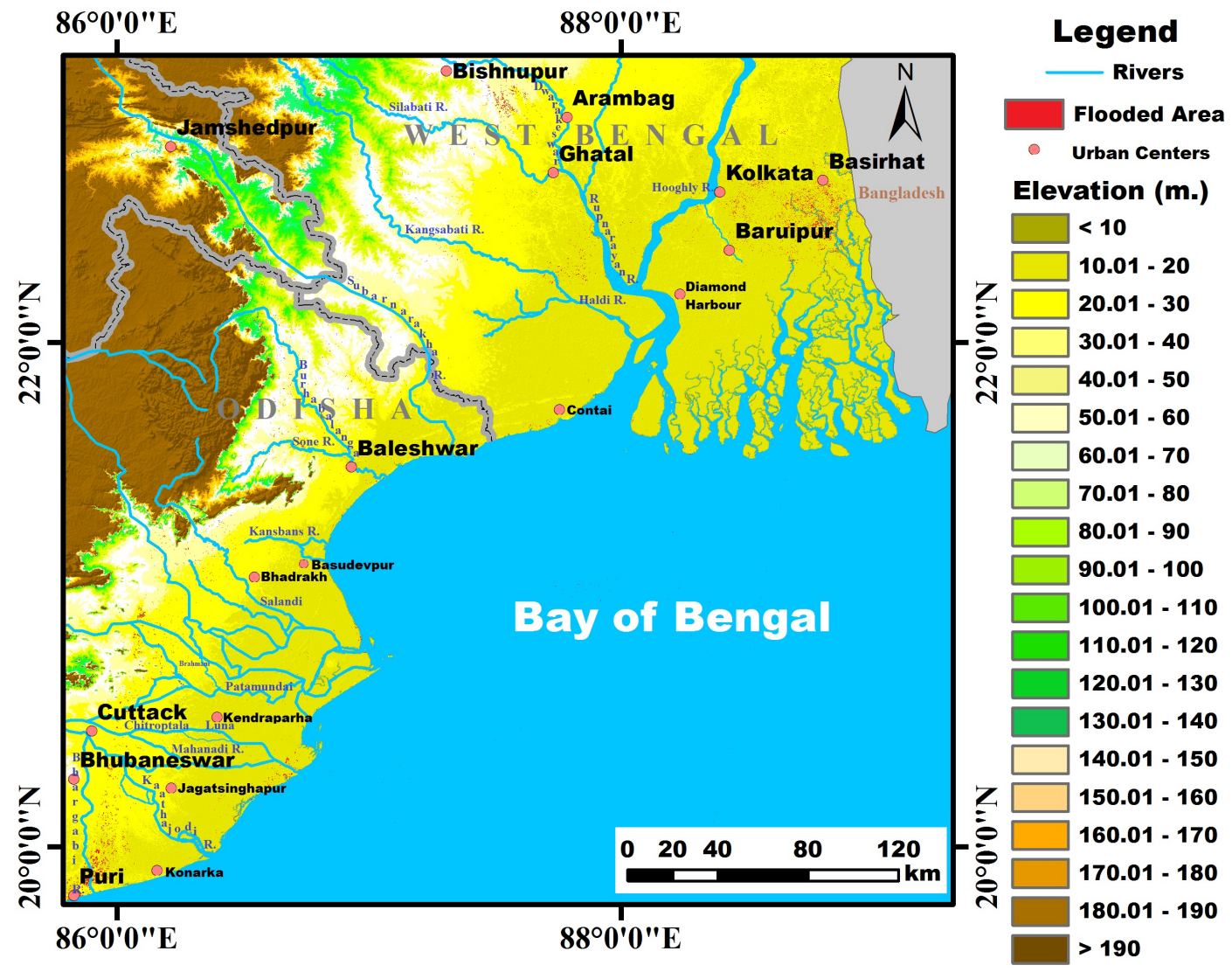

NHESSD

Interactive

comment

Printer-friendly version

Fig. 1. Figure 9: Major drainage system of the study area on NASA's ${ }^{\circledR}$ Shuttle Radar Topography Mission (SRTM) Digital Elevation Models (DEM) with the small to large affected urban centres. 